\title{
Impaired estrogen-induced uterine insulin-like growth factor-I gene expression in the streptozotocin diabetic rat
}

\author{
L. J. Murphy \\ Department of Medicine and Physiology, University of Manitoba, Winnipeg, Manitoba, Canada
}

\begin{abstract}
Summary. Circulating somatomedin-C/insulin-like growth factor-I levels are low in the diabetic rat and unresponsive to exogenous growth hormone. However, the nature of this defect in growth hormone action remains unclear and there is little data on insulin-like growth factor-I gene expression in response to other stimuli and in non-hepatic tissues where insulin-like growth factor-I may have important paracrine and/or autocrine actions. We have previously shown that 17 . beta estradiol stimulates uterine insulin-like growth factor-I expression in the ovariectomised rat. In this report uterine and hepatic insulin-like growth factor-I gene expression have been examined in the streptozotocin-diabetic rat. Serum insulin-like growth factor-I concentrations were significantly reduced in diabetic rats compared to normal rats $(0.72 \pm 0.08$ vs $1.23 \pm 0.05 \mathrm{U} / \mathrm{ml}, p<0.0005)$ and hepatic insulin-like growth factor-I mRNA abundance was similarly reduced in diabetic rats to $49 \pm 5 \%$ of that seen in non-diabetic intact rats $(p<0.005)$. In contrast, uterine insulin-like growth factor-I mRNA abundance was not significantly reduced in diabetic rats compared to control rats $(76 \pm 12 \%, p=\mathrm{NS})$.
\end{abstract}

Although both diabetic and non-diabetic rats demonstrated a significant increase in uterine wet weight following a single injection of 17-beta estradiol the increase in uterine insulinlike growth factor-I expression was significantly less marked in diabetic rats. Acute administration of insulin together with estradiol had no significant effect on serum insulin-like growth factor-I concentrations or hepatic insulin-like growth factor-I mRNA abundance; however, the uterine insulinlike growth factor-I response was significantly $(p<0.01)$ augmented. The observations reported here demonstrate that hepatic insulin-like growth factor-I gene expression is markedly reduced in the diabetic rat and that the estradiolinduced uterine insulin-like growth factor-I response is significantly diminished, consistent with the hypothesis that there is a defect in insulin-like growth factor-I gene activation in the diabetic rat.

Key words: Estrogen, somatomedins, streptozotocin, diabetes, uterine growth.
Experimentally-induced and spontaneous diabetes mellitus in the rodent results in profound growth retardation and a reduction in plasma insulin-like growth factor-I (IGF-I) concentrations [1, 2]. Elevated somatostatin [3] and the consequent reduced growth hormone $(\mathrm{GH})$ secretion have been demonstrated in the diabetic rat [4], however this alone does not explain the growth retardation since these animals are unresponsive to exogenous $\mathrm{GH}[1,5,6]$. The cause of this $\mathrm{GH}$ resistance is not clear but both receptor [5] and post-receptor defects [6] have been proposed. In addition, impaired skeletal growth, poor wound healing [7], diminished proliferation of mesenchymal bone precursor cells [8], and regression of experimental tumours [9] have been documented in the diabetic rodent suggesting that there is a more generalised defect in cellular proliferation in the diabetic rodent [10]. Evidence is available from a number of investigators that circulating IGF-I, predominantly hepatic in origin, is reduced in the diabetic rat; however, there is little data on IGF-I expression in peripheral tissues where IGF-I may have important paracrine and/or autocrine actions. Furthermore, in addition to its role as a mediator of GH action, IGF-I may be involved in other proliferative responses, for example compensatory hypertrophy and/or hyperplasia after partial hepatic and renal resection $[11,12]$. Thus, a defect in IGF-I gene activation in the diabetic animal may explain the impaired proliferative response seen in different tissues.

In previous reports from this laboratory we proposed that IGF-I may function as an estromedin [13] and demonstrated that 17-beta estradiol (E2) increases uterine IGF-I expression in the ovariectomised rat [14]. Since absent or diminished uterine myometrial and epithelial proliferative response to $\mathrm{E} 2$ has been reported in the diabetic rat [15] we have examined the effect of E2 on uterine IGF-I gene expression in the ovariectomised, STZ-diabetic rat. 


\section{Materials and methods}

\section{Animal studies and RNA isolation}

Sprague-Dawley rats, ovariectomised (ovex) at 50-75 g body weight were obtained from Charles River Canada (St.Constance, Quebec) and acclimatised in holding cages for approximately 1-2 weeks. Intact mature female rats of the same strain were obtained from a local source. Animals had achieved a body weight of 200-250 $\mathrm{g}$ at the time of experimentation. For induction of diabetes a single i.p. injection of streptozotocin (STZ, Sigma, St Louis, Mo, USA), $100 \mathrm{mg} / \mathrm{kg}$ body weight (BW) was administered to rats which had been fasted overnight. Control rats received an equivalent volume of citrated buffered saline $\mathrm{pH}$ 3.0. STZ-treated rats which gained less than $1 \mathrm{~g} \mathrm{BW}$ over the subsequent 6 days were considered diabetic. In our experience this criteria invariably correlates with glucourea and significant hyperglycaemia at the time of death on day 6 . On the morning of day 7 , ovariectomised rats received a single i.p. injection of 17 betaestradiol (E2), $5 \mu \mathrm{g} / 100 \mathrm{~g} \mathrm{BW}$, or an equivalent volume of vehicle (5\% ethanol, 95\% phosphate buffered saline) and were killed $6 \mathrm{~h}$ later. This time point was chosen since we have previously shown that maximal uterine IGF-I mRNA abundance occurs $6 \mathrm{~h}$ after E2 injection [14]. Some diabetic rats received $10 \mathrm{U}$ of porcine insulin (Actrapid MC, Connaught Novo, Toronto, Canada) subcutaneously at the time of E2 administration. The uterus and liver tissue were rapidly removed and immediately frozen on dry ice and stored at $-70^{\circ} \mathrm{C}$. Total RNA was extracted from 4 or 5 individual rat liver samples, picked at random from each treatment group, or from pooled uteri from 4-8 rats using the guanidinium isothiocyanate-cesium chloride technique [16]. In some experiments, pooled uterine RNA was obtained from mature virgin diabetic and non-diabetic rats $(200-250 \mathrm{~g} \mathrm{BW})$. These rats were killed at random stages of the estrous cycle since previous studies have shown tht there is only a small change in uterine IGF-I expression throughout the estrous cycle [13].

\section{RNA blot hybridisation}

RNA were separated by electrophoresis in a 1\% agarose, $2.2 \mathrm{~mol} / \mathrm{l}$ formaldehyde gel [17] and transferred to nitrocellulose filters [18]. Filters were prehybridised for $16 \mathrm{~h}$ at $42^{\circ} \mathrm{C}$ in a solution containing $50 \%$ formamide, $20 \mathrm{mmol} / 1 \mathrm{NaH}_{2} \mathrm{PO}_{4}, \mathrm{pH} 7,4 \mathrm{X}$ SSC $(1 \mathrm{X}=$ $0.15 \mathrm{~mol} / 1 \mathrm{NaCl}, 0.015 \mathrm{~mol} / 1$ sodium citrate), $2 \mathrm{mmol} / 1$ EDTA, $4 \mathrm{X}$ Denhardt's solution $(1 \mathrm{X}=0.02 \%$ bovine serum albumin, ficoll and polyvinylpyrrolidine), $0.1 \%$ SDS and $100 \mu \mathrm{g} / \mathrm{ml}$ sonicated, denatured salmon sperm DNA. Hybridisation was performed at $42^{\circ} \mathrm{C}$ in the same solution. Filters were washed initially at room temperature with 2 X SSC and $0.1 \%$ SDS and finally washed for $1 \mathrm{~h}$ at $65^{\circ} \mathrm{C}$ in $0.1 \mathrm{X}$ SSC and 0.1\% SDS. Gel-purified insert of plasmid containing the rat IGF-I cDNA [19] was nick translated to a specific activity of $10^{8} \mathrm{dpm} / \mathrm{ug}$ of DNA using ${ }^{32} \mathrm{P}-\mathrm{dCTP}$ (New England Nuclear, La- chire, Quebec, Canada) and nick-translation reagents obtained from Amersham Canada Ltd. (Oakville, Ontario, Canada). Because of the inherent difficulty in quantitating low abundance transcripts by Northern analysis we also quantitated IGF-I mRNA by dot blot hybridisation. Appropriate serial dilutions of RNA $(5-40 \mu \mathrm{g})$ to yield a linear densitometric signal were immobilised on nitrocellulose paper using a filtration vacuum manifold (Schleicher and Schuell, Keene, NH, USA). The paper was baked, prehybridised, hybridised and washed as described above. Some filters were also hybridised with a ribosomal probe [20] as a control for RNA loading. Autoradiography was performed by exposing Kodak X-Omat AR film (Eastman Kodak, Rochester, NY, USA) to the nitrocellulose filters at $-70^{\circ} \mathrm{C}$ in the presence of an enhancing screen for up to 5 days. Multiple exposures (duration 1-5 days) were analysed by densitometry (Video Densitometer BioRad, Mississauga, Ontario, Canada).

\section{Determination of serum IGF-I and glucose}

IGF-I was measured in acid-extracts of serum [21] from individual rats by a non-equilibrium radioimmunoassay using antisera provided by Drs. J.J. Van Wyk and L. Underwood and distributed by the National Hormone and Pituitary Program. Iodinated trace was obtained from Amersham Canada Ltd. (Oakville, Ontario, Canada) and a serum pool derived from 10 normal male rats $(250-300 \mathrm{~g} \mathrm{BW})$ was used as a standard. Results are expressed as $\mathrm{U} / \mathrm{ml}$ where 1 unit is equivalent to $940 \mathrm{ng}$ of human recombinant IGF-I (Amgen Biologicals, Thousand Oaks, Calif, USA). All samples where a comparison was made were analysed in the same assay. The within assay coefficient of variation was less than $9 \%$. Serum glucose was measured using a glucose oxidase technique (Sigma).

\section{Statistical analysis}

For comparison between treatment groups, individual rat liver RNA samples or uterine RNA samples, pooled from 4-8 rats, were treated as independent observations and compared to a single control pool of hepatic or uterine RNA derived from 11 non-diabetic ovex rats. In each case the IGF-I mRNA concentration in the control RNA pools was arbitrarily attributed a value of 1 . Significant differences between treated and control rats were determined for various parameters using Student's t-test.

\section{Results}

Rats were randomised so that there was no significant difference in the mean body weight in each group of rats at the start of the experiment. The percent change in body weight for each group of animals is shown in

Table 1. Effects of streptozotocin-diabetes on body weight, serum glucose and insulin-like growth factor-I concentrations in rats

\begin{tabular}{lcccc}
\hline & Number & Body weight $\left(\%\right.$ change $\left.{ }^{\mathrm{a}}\right)$ & Glucose (mmol/1) & IGF-I U/ml \\
\hline Non-diabetic intact & $(8)$ & $8.4 \pm 0.8(252.5)$ & $5.6 \pm 0.7$ & $1.09 \pm 0.09$ \\
Non-diabetic ovex & $(6)$ & $7.7 \pm 1.0(259.2)$ & $5.3 \pm 0.4$ & $1.23 \pm 0.15$ \\
Non-diabetic ovex +E2 & $(13)$ & $10.4 \pm 1.2(248.4)$ & $3.0 \pm 0.1$ & $1.13 \pm 0.05$ \\
Diabetic intact & $(6)$ & $-7.1 \pm 2.2(223.8)^{\mathrm{b}}$ & $26.3 \pm 4.7^{\mathrm{b}}$ & $0.60 \pm 0.07^{\mathrm{b}}$ \\
Diabetic ovex & $(12)$ & $-5.3 \pm 1.6(237.2)^{\mathrm{b}}$ & $32.7 \pm 2.4^{\mathrm{b}}$ & $0.72 \pm 0.08^{\mathrm{b}}$ \\
Diabetic ovex + E2 & $(19)$ & $-6.8 \pm 1.2(227.6)^{\mathrm{b}}$ & $6.6 \pm 3.0^{\mathrm{b}}$ & $0.52 \pm 0.06^{\mathrm{b}, \mathrm{c}}$ \\
Diabetic ovex +E2+insulin & $(9)$ & $-7.6 \pm 1.6(216.8)$ & $0.75 \pm 0.10^{\mathrm{b}}$ \\
\hline
\end{tabular}

${ }^{a}$ Percent body weight change over the 7 day period of the study and (absolute weight in grams at the time of death). Data represent mean \pm $\mathrm{SEM} ;{ }^{\mathrm{b}} p<0.0005$ for the difference from the equivalent group of non-diabetic rats. ${ }^{\mathrm{c}} p<0.05 ;{ }^{\mathrm{d}} p<0.0005$ for the difference from diabetic ovex rats 


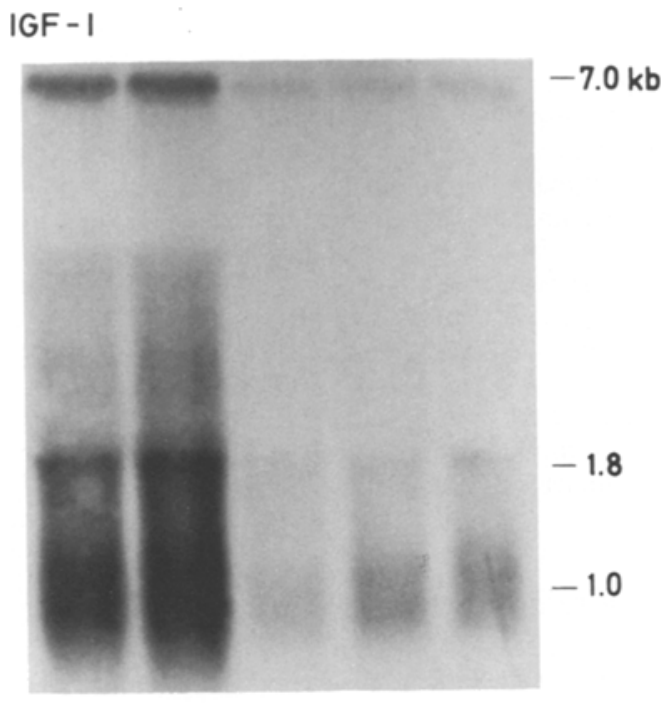

$28 \mathrm{~s}$

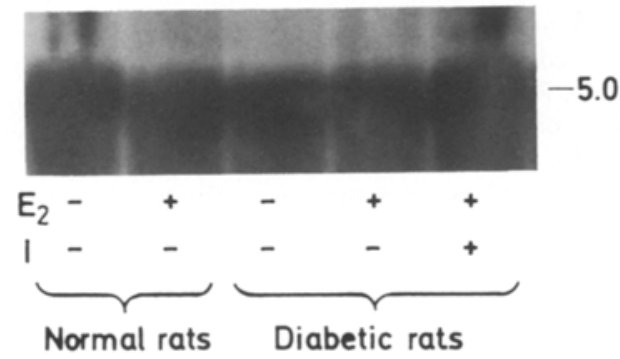

Fig. 1. Northern blot analysis of hepatic RNA from non-diabetic and diabetic ovariectomised rats treated with 17-beta estradiol. Fifty micrograms of total RNA extracted from pooled liver tissue was analysed. The upper panel depicts the pattern of hybridisation obtained with rat IGF-I cDNA while the lower panel shows hybridisation of the same filter with a 28 s ribosomal probe as a control for gel loading. Lane 1 and 2 represent RNA from non-diabetic ovex rats, whereas RNA from diabetic ovex rats has been loaded in lanes 3,4 and 5. Groups of rats treated with estradiol and insulin are shown as $\mathrm{E} 2$ and $\mathrm{I}$ respectively

Table 1. The rats treated with STZ lost approximately $7 \%$ of their body weight over the 7 day period after treatment. In the same period normal rats gained approximately $9 \%$ of initial body weight. In each group of diabetic rats the mean body weight was significantly reduced compared to non-diabetic rats. The serum glucose was significantly elevated $(p<0.0005)$ in all groups of diabetic rats except those which received insulin $6 \mathrm{~h}$ prior to death. Serum IGF-I concentrations were significantly reduced in diabetic rats compared to normal control rats (Table 1). While administration of E2 had no effect on serum glucose or IGF-I concentrations in normal rats, administration of E2 significantly reduced IGF-I concentrations in diabetic rats $(p<0.05$, Table 1). Acute administration of insulin (10 U/rat) lowered serum glucose concentrations in diabetic rats to levels which were not different from control rats; however, serum IGF-I concentrations remained significantly depressed compared to nondiabetic rats $(p<0.0005)$.
Consistent with the reduced serum IGF-I concentration in diabetic rats, hepatic IGF-I expression was decreased in diabetic rats (Fig.1). Each of the major groups of IGF-I transcripts was present in hepatic RNA from diabetic rats and the relative abundance of the various groups of IGF-I transcripts was similar in diabetic and normal rats. When IGF-I mRNA was quantitated in individual liver samples from diabetic rats the mean concentration was reduced to $49 \pm 5 \%$ of that seen in the normal rats $p<0.005$ (Fig. 2). Hepatic IGF-I mRNA abundance was reduced to approximately the same level in both intact and ovex diabetic rats (Fig. 2). Uterine IGF-I mRNA was not significantly different in diabetic compared to non-diabetic rats (Fig. 3).

While STZ-diabetes had little effect on uterine IGF-I mRNA abundance ovariectomy significantly reduced uterine IGF-I mRNA to $18.7 \pm 1.6 \%$ of intact controls, $p<0.01$ (Fig. 3). Ovariectomy had no significant effect on hepatic IGF-I mRNA (Fig.2); nor did administration of $\mathrm{E} 2$ to either diabetic or non-diabetic rats effect hepatic IGF-I expression. Acute administration of insulin did not reverse the diminished hepatic IGF-I mRNA abundance apparent in diabetic rats (Fig. 2).

In contrast to intact rats, uterine IGF-I expression was significantly reduced in ovex-diabetic rats compared to non-diabetic ovex controls (Fig. 3). Furthermore, the uterine IGF-I mRNA response was significantly less in E2-treated diabetic ovex rats than E2-treated non-diabetic ovex rats, $3.56 \pm 0.63$ vs $6.51 \pm 0.75$ arbitrary units, $p<0.05$. In contrast, in diabetic rats which received concurrent administration of insulin at the time of E2 injection, uterine IGF-I expression was significantly enhanced $(p<0.05)$. A similar trend was seen in a separate experiment where insulin and $\mathrm{E} 2$ were administered to diabetic ovex rats; uterine IGF-I was increased $14.3 \pm 2.6$-fold, whereas a $10.4 \pm 1.2$-fold increase was seen in non-diabetic ovex rats injected with E2. In contrast acute administration of insulin alone had no effect on uterine IGF-I mRNA abundance (data not shown).

The effect of E2 on uterine weight is shown in Table 2. Administration of E2 significantly increased uterine wet weight in both diabetic and non-diabetic rats; however, there was no significant difference in E2 induced uterine weight gain seen in diabetic rats compared to normal rats.

As previously reported [14] each of the groups of IGF-I transcripts demonstrable in hepatic RNA was also apparent in RNA extracted from uterine tissue; however, the level of IGF-I expression was considerably lower in uterine tissue compared to hepatic tissue. When analysed by the Northern blot technique, uterine IGF-I expression was reduced in diabetic intact rats compared to normal control rats (Fig. 4A), although this difference did not achieve statistical significance when multiple RNA pools were analysed by 

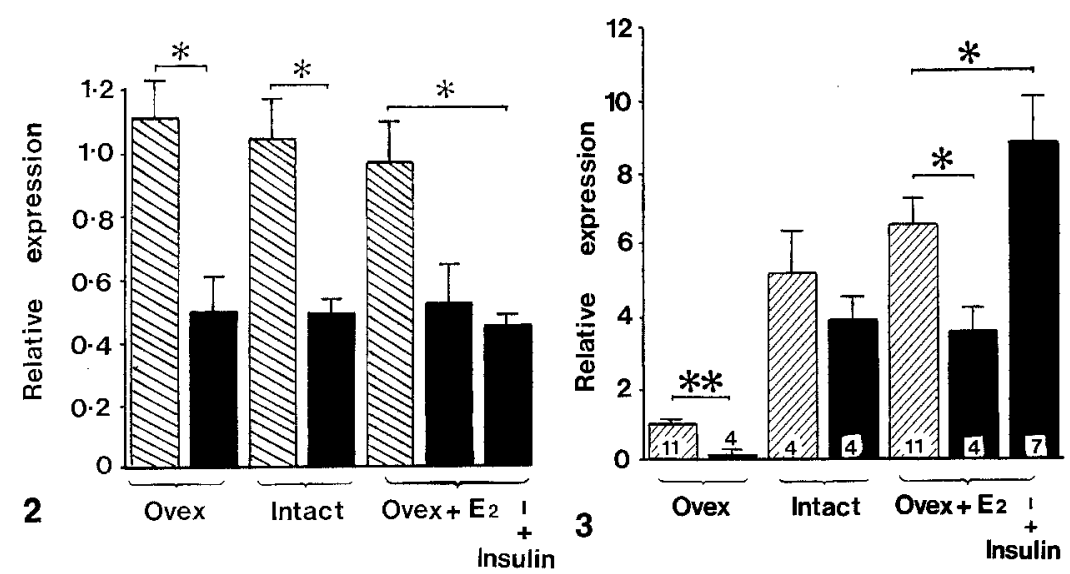

Fig. 2. Hepatic IGF-I mRNA abundance in diabetic and non-diabetic rats. Total RNA pooled from individual rat liver samples was analysed by dot-blot hybridisation with rat IGF-I cDNA. Relative expression of IGF-I was quantitated by comparison with a single RNA pool from

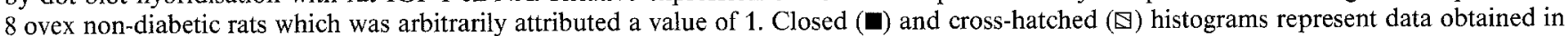
diabetic and non-diabetic rats respectively. Data represent mean \pm SEM of 5 samples per group. ${ }^{*} p<0.005$ for the significant difference between groups

Fig. 3. The effects of estrogen on uterine IGF-I mRNA accumulation in diabetic and non-diabetic rats. Total RNA pooled from 4-8 rat uteri were analysed by dot-blot hybridisation with rat IGF-I cDNA. Relative expression of IGF-I was quantitated by comparison with a single RNA pool from 11 ovex non-diabetic rats which was arbitrarily attributed a value of 1 . Closed ( $\square$ ) and cross-hatched ( $\square)$ histograms represent data obtained in diabetic and non-diabetic rats respectively. Data represent mean \pm SEM. The number of pools (derived from 4-8 rats) of uterine RNA analysed for each treatment group is shown at the base of the histogram. Significant differences between groups, ${ }^{*} p<0.05$ and ** $p<0.005$ respectively

Table 2. Effects of 17-beta estradiol on uterine weight in diabetic and non-diabetic ovariectomised rats

\begin{tabular}{lccl}
\hline Group & Number & Uterine weight & Significance \\
\hline Non-diabetic ovex & 4 & $84.8 \pm 6.3 \mathrm{mgs}$ & \\
Non-diabetic ovex + E2 & 6 & $121.3 \pm 12.0$ & $p<0.05$ \\
Diabetic ovex + E2 & 11 & $111.6 \pm 8.1$ & $p<0.05$ \\
\hline
\end{tabular}

Data represent the mean \pm SEM. The significant difference from untreated ovariectomised rats is shown

dot-blot hybridisation (Fig. 3). Administration of E2 to both diabetic and non-diabetic ovex rats resulted in an increase in IGF-I mRNA abundance; however, this effect was more marked in non-diabetic rats (Fig. 4B and C) confirming the results obtained by dot-blot hybridisation.

\section{Discussion}

Spontaneous and experimentally-induced diabetes in the rodent is characterised by severe growth retardation $[2,6]$ and impaired cellular proliferation in many tissues in response to a number of stimuli [7-9]. Impaired activation of IGF-I gene expression in response to various growth stimuli may account for the defect in cellular proliferation apparent in the diabetic rat. In this report the IGF-I response of the uterus to E2 has been examined to determine whether there is a defect in IGF-I gene activation in the diabetic rat in response to this growth stimulus. The data reported here demonstrate that both hepatic IGF-I mRNA abundance and the E2-induced increase in uterine IGF-I gene ex- pression are significantly reduced in the STZ-diabetic rat.

The abundance of uterine IGF-I mRNAs was significantly less in E2-treated diabetic ovex rats compared to E2-treated non-diabetic ovex rats $(3.56 \pm 0.63$ vs $6.51 \pm 0.75, p<0.05$ ). Since the yield of RNA was similar in all treatment groups, $0.8-1.1 \mathrm{mg} / \mathrm{g}$ wet weight, and equal amounts of RNA from each group were analysed, these data represent an absolute reduction of IGF-I mRNA, and presumably its translated product, in uteri from E2-treated diabetic ovex rats. This observation together with the increase in uterine wet weight demonstrates that while the uterus of the diabetic rat is still able to respond to $\mathrm{E} 2$, the response seen is attenuated in the diabetic rat.

Previous investigations of uterine estrogen responsiveness in the diabetic rat have yielded conflicting data with significant impairment of some but not all parameters of estrogen action. Ekka et al. [22] reported normal estrogen receptors and subcellular distribution of tritiated E2 in the uteri of diabetic rats. Furthermore, E2-induction of the estrogen-induced protein (IP) was similar in diabetic and non-diabetic rats [22]. In contrast, Kirkland et al. [15] reported that while early responses to $E 2$ (such as the increase in uterine weight and luminal cell length) were normal in diabetic rats, a significant defect in DNA synthesis and/or cellular division was apparent in these animals. They concluded that there was an uncoupling of the normal uterine growth response in the diabetic rat so that early responses such as protein and RNA synthesis and cellular hypertrophy proceeded while cellular proliferation was partially blocked. It is of interest 


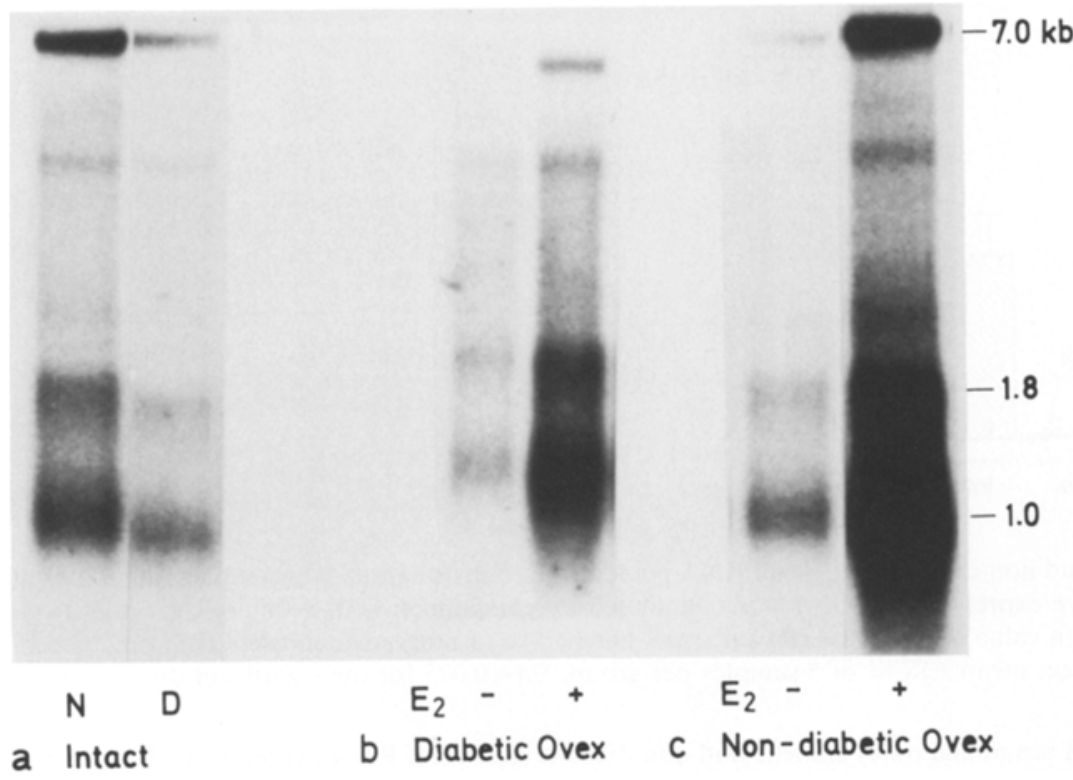

Fig.4. Uterine insulin-like growth factor-I gene expression in diabetic and non-diabetic rats. Ten micrograms of poly (A) ${ }^{+}$RNA pooled from 16-25 rats were analysed by the Northern blot hybridisation. Panel A shows the relative abundance of uterine IGF-I mRNAs in ovaryintact non-diabetic $(\mathrm{N})$ and diabetic (D) rats. Panel B and C depict the effect of a single injection of 17 beta-estradiol on uterine IGF-I mRNA abundance in diabetic and non-diabetic ovariectomised rats. The size of the major IGF-I transcripts is shown that in the $3 \mathrm{~T} 3$ fibroblast model proposed by Stiles et al., [23] IGF-I is not required for early events such as protein and RNA synthesis but is necessary for these cells to enter the S-phase of the cell cycle. If this model is directly applicable to uterine tissue then the subnormal E2-induced IGF-I expression, if associated with reduced uterine IGF-I synthesis and secretion, may explain the partial block in cellular proliferation apparent in the diabetic rat uterus.

In addition to reduced GH secretion an important component of the growth retardation seen in diabetic rodents is resistance to $\mathrm{GH}$ action as determined by the failure of exogenous $\mathrm{GH}$ to stimulate growth and restore low plasma IGF-I concentrations [6, 24]. The mechanisms involved in this apparent resistance to $\mathrm{GH}$ are not known. However, the observations reported by Scheiwiller et al., [25] that administration of IGF-I is able to stimulate growth in diabetic rats supports the hypothesis that the major defect is in activation of IGF-I expression. The data reported here support the hypothesis that there is a defect in IGF-I gene activation in the diabetic rat effecting not only growth hormone-induced IGF-I expression but also IGF-I gene activation in response to another stimuli.

Since uterine estrogen receptor concentrations are normal in the diabetic rat [22], the defect in E2-induced uterine IGF-I expression probably resides at the post-receptor level. A post-receptor defect in GH activation of IGF-I has also been demonstrated in the diabetic rat [6]. It is of interest that insulin appears to rapidly reverse the defect in uterine responsiveness while having no significant short term effects on hepatic IGF-I expression. The failure of insulin to acutely restore hepatic IGF-I expression may reflect a persistent inhibition of pituitary GH secretion rather than continuing hepatic resistance to $\mathrm{GH}$ action. Further studies are necessary to determine whether the im- paired uterine IGF-I response to E2 reported here and the post-receptor defect in $\mathrm{GH}$ action reported previously [6], reflect a more generalised defect in activation of IGF-I expression in the diabetic rat.

Acknowledgements. This research was supported by grants from the MRC Canada, the Manitoba Health Research Council and the Canadian Diabetes Association. The author is the recipient of an MRC Scholarship award. I am grateful to Mr. K. Sharkey for his excellent technical assistance in the animal experiments.

\section{References}

1. Phillips LS, Orawski AT (1977) Nutrition and somatomedins III. Diabetic control, somatomedin and growth in rats. Diabetes 26 : 864-869

2. Takano K, Hizuka N, Shizume K, Hasumi Y, Kogawa M, Tsushima T (1980) Effect of insulin and nutrition on serum levels of somatomedin A in the rat. Endocrinology 107: 1614-1619

3. Tannenbaum GS (1981) Growth hormone secretory dynamics in streptozotocin diabetes: evidence of a role for endogenous circulating somatostatin. Endocrinology 108: 76-82

4. Tannenbaum GS, Colle E, Gurd W, Wanamaker L (1981) Dynamic time-course studies of the spontaneously diabetic BB Wistar rat I. Longitudinal profiles of plasma growth hormone, insulin and glucose. Endocrinology 109: 1872-1879

5. Baxter RC, Bryson JM, Turtle JR (1980) Somatogenic receptors of the rat liver: regulation by insulin. Endocrinology 107: 1176-1181

6. Maes M, Underwood LE, Ketelslegers JM (1986) Low serum somatomedin- $\mathrm{C}$ in insulin-dependent diabetes: evidence for a postreceptor mechanism. Endocrinology 118: 377-382

7. Goodson WH, Hunt TK (1977) Studies of wound healing in experimental diabetes mellitus. J Surg Res 22: 221-227

8. Weiss RE, Reddi AH (1980) Influence of experimental diabetes and insulin on matrix-induced cartilage and bone differentiation. Am J Physiol 238: E200-207

9. Heuson JC, Legros N (1972) Influence of insulin deprivation on growth of the 7,12-dimethylbenz(a)anthracene-induced mammary carcinoma inr ats subjected to alloxan diabetes and food restriction. Cancer Res 32: 226-232 
10. Murphy LJ, Lazarus L (1983) The effect of streptozotocin-induced diabetes mellitus on the ability of rat serum to stimulate human fibroblast proliferation. Endocrinology 112: 1026-1035

11. Russell WE, D'Ercole AJ, Underwood LE (1985) Somatomedin $\mathrm{C}$ /insulin like growth factor I during liver regeneration in the rat. Am J Physiol 284: E618-623

12. Fagin JA, Melmed S (1987) Relative increase in insulin-like growth factor I messenger ribonucleic acid levels in compensatory renal hypertrophy. Endocrinology 120: 718-724

13. Murphy LJ, Murphy LC, Friesen HG (1987) A role for the insulin-like growth factors as estromedins in the rat uterus. Trans Ass Am Physic 99: 204-214

14. Murphy LJ, Murphy LC, Friesen HG (1988) Estrogen induces insulin-like growth factor-I expression in the rat uterus. Mol Endocrinol 1: $445-450$

15. Kirkland JL, Barrett GN, Stancel GM (1981) Decreased cell division of the uterine luminal epithelium of diabetic rats in response to 17-estradiol. Endocrinology 109: 316-318

16. Chirgwin J, Pryzbyla A, MacDonald R, Rutter W (1979) Isolation of biologically active ribonucleic acid from sources enriched for ribonuclease. Biochemistry 18: 5294-5299

17. Lehrach H, Diamond D, Wozney JM, Boedtker H (1977) RNA molecular weight determination by gel electrophoresis under denaturing conditions, a critical reexamination. Biochemistry 16 : 4743-4748

18. Thomas PS (1980) Hybridization of denatured RNA and small DNA fragments transferred to nitrocellulose. Proc Natl Acad Sci USA 77: 5201-5205

19. Murphy LJ, Bell GI, Duckworth ML, Friesen HG (1987) Identification, characterization and regulation of a rat cDNA which encodes insulin-like growth factor-I. Endocrinology 121: $684-691$

20. Gonzalez IL, Gorski JL, Campen TJ, Dorney DJ, Erickson JM, Sylvester JE, Schmickel RD (1985) Variation among human $28 \mathrm{~S}$ ribosomal RNA genes. Proc Natl Acad Sci USA 82: 7666-7670
21. Daughaday WH, Mariz IK, Blethen SL (1980) Inhibition of access of bound somatomedin to membrane receptor and immunobinding sites: a comparison of radioreceptor and radioimmunoassay of somatomedin in native and acid-ethanol-extracted serum. J Clin Endocrinol Metab 51: 781-788

22. Ekka E, Dettertogh R, Vanderheyden I (1978) Oestradiol 2,4,6,7$\left[{ }^{3} \mathrm{H}\right] 17$ uptake and subcellular distribution in the uterus of ovariectomized diabetic rat: induction of early protein synthesis. J Steroid Biochem 9: 833 (Abstract)

23. Stiles CD, Capone GT, Scher CD, Antoniades HN, Van Wyk JJ, Pledger WJ (1979) Dual control of cell growth by somatomedins and platelet-derived growth factor. Proc Natl Acad Sci USA 76: $1279-1283$

24. Phillips LS, Belosky DC, Young HS, Reichard LA (1979) Nutrition and somatomedins VI. Somatomedin activity and somatomedin inhibitory activity in the sera from normal and diabetic rats. Endocrinology 104: 1519-1524

25. Scheiwiller E, Guler HP, Merryweather J, Scandella C, Maerki W, Zapf J, Froesch ER (1986) Growth restoration of insulin-deficient diabetic rats by recombinant human insulin-like growth factor I. Nature 323: 169-171

Received: 3 June 1988

and in revised form: 14 September 1988

\section{Dr. L.J. Murphy}

Room 435

Basic Sciences Building

Department of Physiology

University of Manitoba

770 Bannatyne Ave.

Winnipeg, Manitoba R3E OW1

Canada 